\title{
Exploration of Key Success Factors that Influence Business Performance: The Experiences of Women Micro-entrepreneurs from Mazovia Voivodeship of Poland
}

\begin{abstract}
Women-owned businesses are one of the fastest growing categories of firms in the world, but they are greatly understudied in countries from the Central and Eastern Europe (CEE) [Zapalska et al., 2005]. The purpose of this paper is to examine the relationship between business success predictors and the performance of female-owned micro-enterprises from the Mazovia Voivodeship in Poland during the period 2011-2013, using an Internet-based survey questionnaire. The data were collected by the CAWI (computer assisted web interview) and CATI (computer assisted telephone interview) methods. Exploratory factor analysis, correlation coefficients analysis and multivariate regression models were deployed to investigate the empirical data.

This study contributes to the limited body of literature on factors that positively affect the business performance of female entrepreneurial undertakings, using the context of the Polish experiences. Drawing on Gartner's [1985] typology and "the resource-based view of the firm" theory, a theoretical research model was developed and verified empirically using three multivariate regression models. "Model A" displayed the highest explanatory power of the predicted dependent variable "Composite business performance" $\left(\mathrm{R}^{2}=42,3\right)$.

Our findings suggest that the most successful female business owners in the region were ideally 30-39 years old; completed a university education; had at least three years of business experience; displayed above average entrepreneurial orientation; and adopted a business strategy to deal with competitors. Moreover, the better performing women-owned micro-enterprises hired qualified and experienced employees ("hman capital"); offered


products or services to domestic and international customers; were able to attract business sector clients; and had sufficient resources ("financial capital"). It is recommended that this research be replicated in other countries from the CEE region (e.g. Czech Republic) for comparative purposes.

Keywords: business performance, micro-enterprise, Poland, success factors, woman micro-entrepreneur

JEL: C21, L10, M19, M21, M31

\section{Introduction and Research Problem Formulation}

The number of female-owned firms continues to rise around the world. Today, more women choose small business ownership as a career path in comparison with full-time employment because of the flexibility it provides to balance work and family obligations [Carter et al., 2012]. Consequently, studies indicate that these firms contribute significantly to the economic progress of local communities in many countries around the world [Kelly et al., 2013].

Regretfully, since the early 1980 s and continuing until the early 2000 s, most studies on women's entrepreneurship mainly concerned developed countries (e.g. the USA). This is because many researchers in the field, especially by the late $1990 \mathrm{~s}$, assumed that female and male business owners did not differ in the way they managed their firms. Thus, they assumed that knowledge gathered about businesses owned by men applied equally to women and, as a result, women did not need to be studied independently [Jennings, Brush, 2013].

The existing findings from developed countries may not be relevant to the business practices of women micro-entrepreneurs from the Central and Eastern Europe (CEE) countries. These nations share similar experiences of transition from central planning to a market-based economy and display many "differences in economic, institutional and cultural characteristics" from mature market-based economies [Yordanova, 2011].

Moreover, women are still "one particularly understudied group of entrepreneurs" in comparison with their male counterparts [McGrath Cohoon et al., 2010, p. 3]. In transition countries from the CEE region, the studies on female entrepreneurship are few [Zapalska et al., 2005] and there is a lack of systematic knowledge about the performance of women business owners [De Bruin et al., 2006; PARP, 2011; Ramadani et al., 2015].

Moreover, most works that do study the business practices of women entrepreneurs do not focus on factors that favorably influence the business performance of female-owned firms in the CEE region. This study attempts to address that knowledge gap through the development of a theoretical research model (see Figure 1). This model is empirically tested on the population of women micro-entrepreneurs operating within the Mazovia Voivodeship in Poland. 
Specifically, the objective of this study is to explore the relationship between plausible business success predictors and the performance of female-owned firms using data for the Mazovia Voivodeship of Poland during 2011-2013. Mazovia Voivodeship was selected because of its importance to the country in terms of the GDP per capita growth; exports and imports; and its ability to attract the highest number of foreign investments [Guzowska, 2011].

This paper is structured in the following manner. First, we briefly summarize the relevant literature on women's entrepreneurship around the world. Next, we describe our theoretical research model, which was developed specifically for women-owned micro-enterprises. The subsequent section explains the methodological approach used to analyze the empirical data. We then profile the investigated women micro-entrepreneurs from the Mazovia Voivodeship and briefly discuss the main characteristic features of their firms. Our results are divided into three sections for clarity of the data analysis presented. We begin with the results of our exploratory factor analysis, followed by our correlation coefficients analysis findings and an explanation of the three investigated multivariate regression models - A, B and C. The study results are then presented with references to relevant literature on the topic, followed by a brief section that highlights the key limitations of this research. The paper concludes with a summary of our findings, which also provides some recommendations for future research in the field.

\section{Literature Review}

The phenomenon of women's business ownership started to draw the attention of researchers from the entrepreneurship and business management fields of study in the late 1970 s [Jennings, Brush, 2013]. These initial studies were carried out mainly within the most developed countries of the world (e.g. the USA) [Valencia, 2007]. However, since the late $1990 \mathrm{~s}$, there has been a growing body of research around the world on this sub-population of firms. This is because such firms contribute significantly to the economic progress and job creation in many countries [Carter et al., 2001]. The extant literature on this phenomenon can be grouped into four distinct categories following Gartner's [1985, pp. 696-706] theoretical framework, which identified four distinct research dimensions, namely: the individual (or individuals); the organization; the process; and the environment.

Studies focusing on the individual (or individuals) dimension concentrated on the socio-demographic and psychological characteristics of women business owners [Valencia, 2007]. The latest report by the Global Entrepreneurship Monitor (GEM) revealed that female-owned firms are not a homogeneous group when comparing different geographical regions. Its findings disclosed that age-related patterns of women entrepreneurial activities are relatively consistent around the world. However, the 25-34 age group tends 
to predominate among females at an early-stage of entrepreneurship. GEM studies also show that women entrepreneurs tend to have consistently higher levels of education (a post-secondary or higher level) across the globe than females who are non-entrepreneurs [Kelley et al., 2015].

Studies of the psychological traits of women entrepreneurs sought to distinguish key factors that motivated females to create new firms [Valencia, 2007]. Within this stream of research, scholars classified - as the main variables that influenced women business owners in establishing their own firms - "necessity-push" (e.g. dissatisfaction with a job, difficulty in finding full-time employment, etc.) and "opportunity-pull" motivations (e.g. achieving self-accomplishment, desire for social recognition, etc.) [Orhan, 2005].

Research focusing on the organization examined women-owned firms with regard to the businesses actually owned; the sectors of the economy in which they operated; the type of management strategies adopted; firm performance; and the factors that facilitated their success [Valencia, 2007]. These studies revealed that female-owned firms are typically small in size, consumer segment oriented, traditionally active in the services sector; and pursue slower-growth strategies [Minniti et al., 2005]. Some authors found that women-owned businesses also display lower economic performance than do male-owned firms [Fischer et al., 1993]. However, other scholars suggest that both female and male entrepreneurs perform similarly when a broader range of success outcome variables are considered (e.g. the owners' expectations, pursued business goals, etc.) [Watson, Robinson, 2003].

Research on process examined women's business startup activities, the strategies they used, and the different models around which their firms were organized [Valencia, 2007]. Women business owners prefer to partner with those they know well (e.g. spouse, family member, etc.) or maintained long-term close social relations (e.g. close friend, work colleague, etc.). Female entrepreneurs are also more comfortable co-managing their firms with another woman because they usually create an effective management team. Networking and social capital were also found to be important factors for women in the process of establishing their own firms [Aldrich et al., 2002].

The last stream of research explored the business environment dimension of women entrepreneurship, which is a contextual phenomenon. These studies investigated such aspects as the accessibility and availability of debt capital; the role of mentoring; the existence of informal institutions and networking; as well as the social attitudes towards women's entrepreneurship from cultural and family relationship perspectives [Valencia, 2007]. Some authors found that women business owners tend to create more social networks, consisting of many informal relationships (often predominantly with other females) than do their male counterparts [Buttner, Moore, 1997].

In this study, the first two categories of Gartner's [1985] classification were used to develop our theoretical research model (see Figure 1 below). 


\section{Description of the Theoretical Research Model}

Figure 1 displays a theoretical research model of the determinants of success in business designed for women-owned (e.g. sole proprietorship) and co-owned (e.g. civil law partnership) micro-enterprises operating in the Mazovia Voivodeship of Poland. This model was developed based on Gartner's [1985] theoretical framework for describing a new venture creation, "the resource-based view of the firm" theory drawn from Grant [2010, pp. 122-125] and an extensive literature review of key success factors in women's entrepreneurship ventures (see Figure 1 and the description of model variables discussed below). The presented model was also critically evaluated at international $\mathrm{PhD}$ conferences in Poland and abroad, as well as at Warsaw School of Economics PhD seminars to improve its theoretical relevance and research quality.

FIGURE 1. Theoretical research model exploring the key success factors in business developed for women-owned and co-owned micro-enterprises from the Mazovia Voivodeship of Poland.

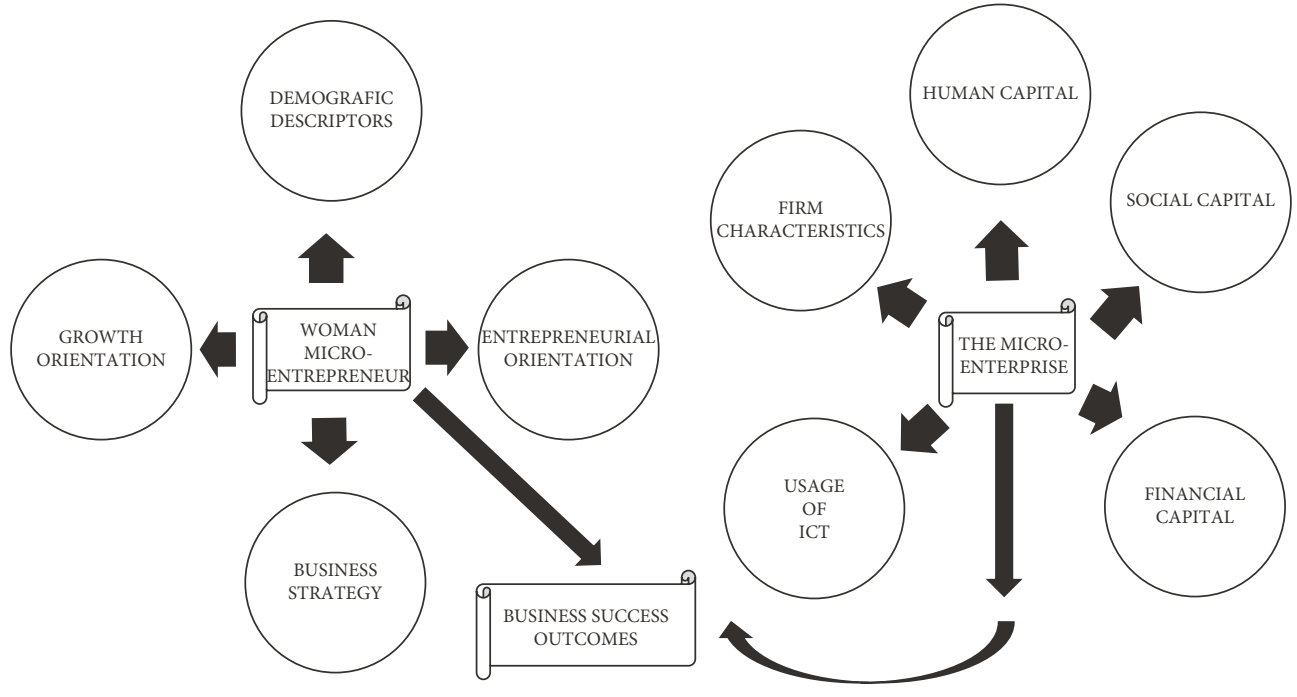

Source: own elaboration.

The theoretical research model presented in Figure 1 shows the assumed linkages between the plausible business success predictors and the achieved business success outcomes by women micro-entrepreneurs. Business success outcomes are measured using the dependent variable "Composite business performance". The examined predictors of business success were grouped into two distinct research categories. One refers to the 
characteristics of a woman micro-entrepreneur, and the other concerns firm characteristics and the resources owned by the micro-enterprise.

Success in business has been defined as the achievement of a "favorable or desired outcome" [Merriam-Webster, 2015]. In the literature the success of micro and small businesses is measured through growth, performance, profitability, excellence and survival [Robichaud et al., 2010, p. 40]. However, scholars are not unanimous in their understanding of how business success should be understood and measured in practice [Fielden, Davidson, 2010]. This is because success is a multidimensional concept [Iakovleva, Kickul, 2006].

In this study, we understand success in terms of the economic performance of women-owned and co-owned micro-enterprises. This construct was measured by a dependent variable entitled "Composite business performance". It was calculated as a mean of four performance-related items from the questionnaire that were evaluated on a 7-point itemized rating scale developed by the author. The scale ranged from 7 = "Increased very much" to 1 = "Decreased very much." The neutral point was labeled as 4 = "Did not change." These four performance-related items were summated into a composite scale that was tested using an Internet-based questionnaire by a third-party research company and was proved to be reliable.

The four indicators used to gauge the economic performance of micro-enterprises were: "the change in the level of annual revenue from economic activity (net of VAT) during the 2011-2013 period"; "the change in the level of annual net profit or self-employment earnings after tax during the 2011-2013 period"; "the change in the amount of net profit or self-employment earnings after tax used by the women micro-entrepreneur each year for investment in the business during that period"; and lastly "the change in the number of customers served during that period".

The three financial business performance indicators were developed by the researcher from an analysis of the Polish tax return (PIT 36), which is filed annually by owners and business partners of micro-enterprises. The fourth measure of performance, relating to "the change in the number of customers", was recommended by women micro-entrepreneurs who participated in a pilot testing of the questionnaire. These indicators provide simple measures of economic performance that were reasonably well understood by women micro-entrepreneurs during the pilot study of the questionnaire, in contrast to more complex measures like accounting ratios (e.g. return on sales).

The indirect approach to measure business performance of micro-enterprises is often applied in the research when direct access too, or the availability of, actual economic data is lacking (e.g. sales revenue, net profit, etc.). The measures of firm performance used in the questionnaire, which are summated into a composite scale, are considered good proxy indicators of the actual economic results achieved by the responding firms [Lumpkin, Dess, 2001].

There is some variation among scholars of entrepreneurship and small business management, on the best combination of independent variables that differentiate better 
performing firms from the less successful ones [Robichaud et al., 2010]. This study explored plausible predictors of success, which were grouped into the characteristics of a woman micro-entrepreneur and the characteristics, as well as the resources of the micro-enterprise (see Figure 1). The first category comprises "demographic descriptors", "entrepreneurial orientation", "business strategy" and "growth orientation." The second grouping encompasses "human capital", "social capital", "financial capital", "the usage of information and communication technology (ICT)", as well as various predictors and control variables included under the umbrella of "firm characteristics".

Demographic descriptors relate to such independent variables as the "age of an entrepreneur"; "formal education"; "managerial and industry experience"; "family history" associated with self-employment; "marital status"; "gender"; and "rank among immediate family members" [Robichaud et al., 2010, p. 40].

Entrepreneurial orientation captures the policies and practices adopted by the business owner. This concept may be understood as a strategy-making process that is used by female entrepreneurs to formulate their firm's mission, develop their long-term vision and establish a competitive advantage in the market. The main dimensions of entrepreneurial orientation consistently used in the literature are: innovativeness, risk-taking and pro-activeness [Rauch et al., 2009, pp. 763-764].

Grant [2010, pp. 16-18] defines business strategy as "the means by which individuals and organizations achieve their objectives". A well-designed strategy comprises the following components: simple and consistent objectives with a long-term focus; a good understanding of the firm's business environment; a fair evaluation of the firm's resources; and effective implementation. Its formulation and practical adoption is important for achieving success by micro-enterprises [Lemańska-Majdzik, 2009].

Growth can be understood as "the process of increasing in size" that occurs over a specified period of time [Oxford University Press, 2016]. This concept can measure change (e.g. volume of sales) when the firm expands. Growth can also describe a process of firm expansion that results in an increase in magnitude or an improvement in quality [Davidsson et al., 2010]. Thus, the growth orientation construct captures the choices and decisions women business owners make when the object of their firms is to expand in the future [Kelley et al., 2011].

Human capital is an assessment of the economic value of a person's skill set. This concept recognizes that the productivity and skills of employees, as well as their usefulness to the company, can be significantly improved by investing in education, acquiring business experience or upgrading their professional abilities [Investopedia, 2016]. A person's human capital components are their age, professional business experience and completion of a formal education [Parker, 2009].

Davidsson and Honig [2003, p. 307] define social capital as "the ability of actors to extract benefits from their social structures, networks and relationships". Social capital includes such groups as immediate and extended family, close friends, local communities, and 
business as well as work contacts [Parker, 2009, pp. 119-121]. Women micro-entrepreneurs can benefit from their engagement in personal and professional social networks that contribute to the firm's survival, as well as long-term success [McGrath Cohoon et al., 2010].

Micro-enterprises that strive to succeed in a competitive market must acquire sufficient financial capital from various sources (e.g. own funds, bank loans, etc.) to fund their operations and facilitate long-term growth [Carter et al., 2012]. Studies on women's entrepreneurial undertakings indicate that females often had less capital at startup as compared to males [Carter, Allen, 1997]. This funding deficit when firms are formed adversely affected their performance and prospects for future development [McAdam, 2013].

Computers, software, the Internet and modern communication technology have revolutionized how business organizations are managed. Information and communication technology (ICT) are viewed as one of the most important factors that impact the profitability and growth of enterprises around the world [Stair Jr. et al., 1989]. The implementation of ICT allows firms to reduce operating costs, improve management efficiency, and increase profitability [Nordin et al., 2011].

Firm characteristics include such organizational variables as enterprise age; company size; legal form; the number of founders; initial start-up capital; and the extent to which net earnings are reinvested in the business [Parker, 2009, pp. 320-321]. Studies reveal that venture team size [Westhead, Howarth, 2006] and operating a firm as a limited liability [Capelleras, Greene, 2008] are associated with the growth intentions of the owners.

Finally, in this study, the control variables such as "business location", "legal form", "economic activity classification" (under PKD-2007) ${ }^{2}$ and "micro-enterprise size" (measured in terms of the number of employees and revenue size) were used in the three multivariate regression models. Their inclusion in the statistical data analysis was made to capture their indirect impact (positive or adverse) on the investigated dependent variable "Composite business performance". The control variables were grouped within the micro-enterprise firm characteristics (see Figure 1).

\section{Research Method}

This study was designed as exploratory in nature. As a result, the researcher sought to answer the following research question:

- "What key factors positively influenced the achievement of success in business by women micro-entrepreneurs who operated their firms, located within the Mazovia Voivodeship of Poland, during 2011-2013?"

To address this research question a cross-sectional design was adopted. ${ }^{3}$

The target population comprised of women-owned (e.g. sole proprietorship) and co-owned (e.g. civil law partnership) micro-enterprises registered in the Mazovia Voivodeship in Poland. The legal form of the examined companies included sole proprietorships, 
partnerships, limited partnerships and limited liability companies in which the combined ownership share of women was at least $51 \%$ of total assets. The study included micro-enterprises from all sectors of the economy. The firms selected for the survey had to operate for a minimum of three years. A woman-owned micro-enterprise was defined as a legally independent business entity that hired less than 10 employees during the 2011-2013 period and generated an annual turnover of below 2 million EUR. The surveyed female-owned firms were drawn using a systematic sampling method. ${ }^{4}$ The target sample size established for the study was 3,000 women business owners. ${ }^{5}$

The questionnaire was pilot tested on a small sample $(n=11)$ of women-owned firms from the Mazovia Voivodeship. For this purpose semi-structured interviews were conducted to ensure the reliability and validity of the questionnaire. The respondents were selected using a snowball sampling method. ${ }^{6}$

The design, testing, and use of the Internet-based questionnaire to conduct the survey was outsourced to a professional market research company. ${ }^{7}$ The validity and reliability of the data collection process was performed according to the acceptable research standards. The survey was administered by a combination of CAWI (computer assisted web interview) and CATI (computer assisted telephone interview) research methods between September 10 and September 30, 2014. At the end of the survey, 309 respondents filled out a valid online questionnaire, constituting an acceptable response rate of $14 \% .{ }^{8} \mathrm{Zikmund}$ et al. [2009, p. 233] regard response rates from E-mail or Internet-based surveys ranging between 10 and $15 \%$, as good indicators of the data collection process when no special considerations (e.g. product samples, money vouchers, etc.) are used to significantly increase the respondent participation rates.

The dependent and independent variables, used in the exploratory factor analysis, were measured on either a 7-point itemized rating scale or a 7-point Likert scale. In the case of categorical variables, which had more than two categories as predictors, dummy variables were created with the aid of frequency distribution tables for each variable in order to use them in multivariate regression models. ${ }^{9}$

The data analysis relied on the IBM ${ }^{\oplus}$ SPSS ${ }^{\bullet}$ Statistics ver. 21 software package. Frequency tables, descriptive statistics methods, diagrams and cross-tabulations were deployed in the initial exploration of the independent variables. Exploratory factor analysis was used to create five factors, which were later summated into composite scales. Pearson's r, Spearman's rho and Kendall's tau correlation coefficients were calculated to detect statistically significant associations with the dependent variable "Composite business performance". The identified plausible success predictors were used in the evaluation of three multivariate regression models $\mathrm{A}, \mathrm{B}$ and $\mathrm{C}$ to identify the one with the highest explanatory power. 


\section{The Characteristic Features of Surveyed Women Micro-entrepreneurs and their Firms ${ }^{10}$}

The dominant age category of women business owners was the "30-39 years age group" $(34,6 \%)$. The majority of surveyed women micro-entrepreneurs $(78 \%)$ completed some form of university education (45\%). Most surveyed females had "6-10 years" of practical business experience in the industry (34\%). The overwhelming majority of women micro-entrepreneurs $(91,9 \%)$ operated as sole proprietors, with only $2,6 \%$ being limited liability companies. Most female business owners were in consumer services $(72,8 \%)$. The selection of specific economic activity by women reflected their level of education, prior work experience, and business experience.

The largest concentration of female-owned micro-enterprises $(58,9 \%)$ was in Warsaw (Poland's capital). Only $11 \%$ of respondents were from rural areas. In terms of firm size, $54,7 \%$ of the surveyed women-owned firms operated as self-employed entities. Only 8,1\% had more than six workers. The majority of women business owners $(79,9 \%)$ reported that during 2011-2013 their business operations were mainly funded from internal sources (e.g. retained earnings). Bank loans $(11,7 \%)$ were the largest external source of finance reported by the respondents.

\section{Presentation of Study Findings: Exploratory Factor Analysis}

An exploratory factor analysis was used for data reduction purposes to create a new set of variables (i.e. extracted factors) to replace the original variables from the questionnaire. The rationale for applying this method was to retain the character of the variables within each question of the questionnaire while reducing their number used in the multivariate regression models. The data analysis procedures recommended by Hair Jr. et al. [2014, pp. 89-149] and Field [2013, pp. 665-719] were followed.

Table 1 summarizes the exploratory factor analysis. Five factors were extracted using the principal components technique with an unrotated factor solution. This technique was applied to summarize most of the original information found in the data (i.e. the total variance) in a minimum number of factors [Hair Jr. et al., 2014]. All investigated variables had factor loadings in excess of 0,500 , indicating they are statistically significant at an a significance level of 0,05 for the sample size of 309 observations [Hair Jr. et al., 2014]. A factor loading shows how a measured variable is strongly correlated with the extracted factor [Zikmund et. al., 2009]. For example, the variable " $\mathrm{X}_{18 \mathrm{~A}}$ : (item 1)" contributed a loading of 0,967 (96,7\%) towards the extracted factor called "Composite business performance". 
Eigenvalues measure how much variance is explained by each extracted factor. The factors are extracted by using eigenvalues greater than 1,0 as a guideline. In this study only five factors were extracted [Field, 2013]. The factor labeled "Composite business performance" resulted in the highest eigenvalue of 3,601 and explained as much as 90,02\% of the total variance. By contrast, the factor "Social capital" generated the lowest eigenvalue equal to 1,748 and explained only $43,7 \%$ of the total variance.

\section{TABLE 1. Summary statistics of the exploratory factor analysis output for the five extracted factors}

\begin{tabular}{|c|c|c|c|c|c|}
\hline \multirow[b]{2}{*}{$\begin{array}{l}\text { Variables investigated } \\
\text { (items in questionnaire } \\
\text { used to measure each } \\
\text { construct) })^{11}\end{array}$} & \multicolumn{5}{|c|}{ Factor extracted } \\
\hline & $\begin{array}{l}\text { Composite } \\
\text { business } \\
\text { performance }\end{array}$ & $\begin{array}{c}\text { Entrepreneurial } \\
\text { orientation }\end{array}$ & $\begin{array}{c}\text { Growth } \\
\text { orientation }\end{array}$ & $\begin{array}{l}\text { Usage of } \\
\text { information and } \\
\text { communication } \\
\text { technology (ICT) }\end{array}$ & $\begin{array}{l}\text { Social } \\
\text { capital }\end{array}$ \\
\hline \multicolumn{6}{|c|}{ Unrotated factor loadings per variable: } \\
\hline \multicolumn{6}{|c|}{ Composite business performance: } \\
\hline $\mathrm{X}_{18 \mathrm{~A}}:$ Item 1 & 0,967 & & & & \\
\hline $\mathrm{X}_{18 \mathrm{~B}}:$ Item 2 & 0,969 & & & & \\
\hline $\mathrm{X}_{18 \mathrm{C}}:$ Item 3 & 0,950 & & & & \\
\hline $\mathrm{X}_{18 \mathrm{D}}:$ Item 4 & 0,908 & & & & \\
\hline \multicolumn{6}{|l|}{ Entrepreneurial orientation: } \\
\hline $\mathrm{X}_{22 \mathrm{~A}}:$ Item 1 & & 0,859 & & & \\
\hline $\mathrm{X}_{22 \mathrm{~B}}:$ Item 2 & & 0,769 & & & \\
\hline $\mathrm{X}_{22 \mathrm{C}}:$ Item 3 & & 0,829 & & & \\
\hline $\mathrm{X}_{22 \mathrm{D}}:$ Item 4 & & 0,502 & & & \\
\hline \multicolumn{6}{|l|}{ Growth orientation: } \\
\hline $\mathrm{X}_{24 \mathrm{~A}}:$ Item 1 & & & 0,787 & & \\
\hline $\mathrm{X}_{24 \mathrm{~B}}:$ Item 2 & & & 0,767 & & \\
\hline $\mathrm{X}_{24 \mathrm{C}}:$ Item 3 & & & 0,617 & & \\
\hline $\mathrm{X}_{24 \mathrm{D}}:$ Item 4 & & & 0,821 & & \\
\hline \multicolumn{6}{|c|}{ Usage of information and communication technology (ICT): } \\
\hline $\mathrm{X}_{26 \mathrm{~A}}:$ Item 1 & & & & 0,505 & \\
\hline $\mathrm{X}_{26 \mathrm{~B}}:$ Item 2 & & & & 0,787 & \\
\hline $\mathrm{X}_{26 \mathrm{C}}:$ Item 3 & & & & 0,721 & \\
\hline $\mathrm{X}_{26 \mathrm{D}}:$ Item 4 & & & & 0,703 & \\
\hline \multicolumn{6}{|l|}{ Social capital: } \\
\hline $\mathrm{X}_{33 \mathrm{~A}}:$ Item 1 & & & & & 0,588 \\
\hline
\end{tabular}




\begin{tabular}{|c|c|c|c|c|c|}
\hline \multirow[b]{2}{*}{$\begin{array}{c}\text { Variables investigated } \\
\text { (items in questionnaire } \\
\text { used to measure each } \\
\text { construct })^{11}\end{array}$} & \multicolumn{5}{|c|}{ Factor extracted } \\
\hline & $\begin{array}{l}\text { Composite } \\
\text { business } \\
\text { performance }\end{array}$ & $\begin{array}{l}\text { Entrepreneurial } \\
\text { orientation }\end{array}$ & $\begin{array}{c}\text { Growth } \\
\text { orientation }\end{array}$ & $\begin{array}{c}\text { Usage of } \\
\text { information and } \\
\text { communication } \\
\text { technology (ICT) }\end{array}$ & $\begin{array}{l}\text { Social } \\
\text { capital }\end{array}$ \\
\hline $\mathrm{X}_{33 \mathrm{~B}}:$ Item 2 & & & & & 0,526 \\
\hline $\mathrm{X}_{33 \mathrm{C}}:$ Item 3 & & & & & 0,804 \\
\hline $\mathrm{X}_{33 \mathrm{D}}:$ Item 4 & & & & & 0,693 \\
\hline \multicolumn{6}{|c|}{ Exploratory factor analysis summary: } \\
\hline $\begin{array}{l}\text { Eigenvalues } \\
\text { (Sum of Squares) }\end{array}$ & 3,601 & 2,268 & 2,262 & 1,888 & 1,748 \\
\hline $\begin{array}{l}\text { Percentage of variance } \\
\text { explained by each factor }\end{array}$ & $90,02 \%$ & $56,71 \%$ & $56,54 \%$ & $47,21 \%$ & $43,70 \%$ \\
\hline Cronbach's alpha (4 items) & 0,963 & 0,694 & 0,740 & 0,626 & 0,531 \\
\hline Cronbach's alpha (3 items) & N/A & 0,787 & N/A & N/A & 0,541 \\
\hline
\end{tabular}

Note: A principal components analysis was selected to extract the five factors using the unrotated component factor solution. Factor loadings of over 0,500 per variable are shown in Table 1 . Number of observations n=309. N/A means "not applicable". Source: own elaboration.

Cronbach's alpha ( $\alpha$ ) coefficient was calculated to test the reliability of the scales that measured each extracted factor. This statistic evaluates the internal consistency of all variables that comprise the composite scale and ranges from 0 to 1 [Hair Jr. et al., 2014]. The Cronbach's alpha statistic for "Composite business performance", which includes all four items from the questionnaire, is equal to 0,963 . This result indicates a very high reliability of the overall scale used to measure this construct. In turn, the value of Cronbach's alpha statistic for "Social capital", which includes three items from the questionnaire with the highest factor loadings, amounts to only 0,541 . This result shows a rather low level of reliability of the overall scale used to measure this construct. However, due to the exploratory nature of this study, the achieved value of this statistic for "Social capital" may be regarded as marginally acceptable. In the case of the extracted factors "Entrepreneurial orientation" and "Social capital", the Cronbach's alpha coefficient was recalculated for only three items from the questionnaire to improve the overall reliability of their scales.

During the last stage of analysis, a combined scale was computed for all five extracted factors following the recommendation by Hair Jr. et al. [2014, pp. 124-126]. Consequently, for "Composite business performance", "Growth orientation" and the "Usage of information and communication technology (ICT)", four items were used to calculate a combined scale. However, for "Entrepreneurial orientation" and "Social capital" only three items were included to compute a combined scale. The five factors were further used in multivariate regression analysis. 


\section{Presentation of Study Findings: Correlation Coefficients Analysis}

Pearson's correlation coefficient ( $\mathrm{r}$ ), Spearman's correlation coefficient ( $\rho$ or rho) and Kendall's correlation coefficient ( $\tau$ or tau) were used to detect statistically significant correlations between the dependent variable "Composite business performance" and plausible business success predictors.

Table 2 summarizes the results for the three correlation coefficients. All categorical predictors were recorded into dichotomous (for two categories) or dummy variables (in case of more than two categories) with values of one or zero to be used subsequently in the multivariate regression models.

The correlation coefficients results show that "Entrepreneurial orientation", "Age - up to 39 years", "Education level - university and higher" and "Micro-enterprise growth" demonstrated the highest level of positive association with the dependent variable "Composite business performance." In the case of "Entrepreneurial orientation" and the "Age - up to 39 years" variables, the correlation was moderately strong in magnitude in terms of the size of the effect. ${ }^{12}$

TABLE 2. The results of correlation coefficients for business success predictors and control variables

\begin{tabular}{|c|c|c|c|}
\hline Investigated variables & Pearson's $\mathrm{r}$ & $\begin{array}{c}\text { Spearman's } \\
\text { rho }(\rho)\end{array}$ & $\begin{array}{c}\text { Kendall's tau } \\
(\tau)\end{array}$ \\
\hline \multicolumn{4}{|l|}{ 1. Dependent variable (i.e. predicted variable): } \\
\hline Y: Composite business performance & 1,000 & 1,000 & 1,000 \\
\hline \multicolumn{4}{|c|}{ 2. Independent variables (i.e. business success predictors): } \\
\hline $\mathrm{X}_{3}:$ Role in business & $0,140\left(^{*}\right)$ & $0,135\left(^{*}\right)$ & $0,114\left(^{*}\right)$ \\
\hline $\mathrm{X}_{4}$ : Business partners & $0,126\left(^{*}\right)$ & $0,136\left(^{*}\right)$ & $0,113\left(^{*}\right)$ \\
\hline $\mathrm{X}_{8}$ : Business experience & $-0,344(* *)$ & $-0,384(* *)$ & $-0,274(* *)$ \\
\hline $\mathrm{X}_{9 \mathrm{a}}:$ Markets served - Local & $-0,206\left(^{* *}\right)$ & $-0,204(* *)$ & $-0,172(* *)$ \\
\hline $\mathrm{X}_{9 \mathrm{~b}}:$ Markets served - Regional & 0,019 (NS) & 0,012 (NS) & $0,010(\mathrm{NS})$ \\
\hline $\mathrm{X}_{9 \mathrm{c}}:$ Markets served - Domestic & $0,114\left(^{*}\right)$ & $0,123(*)$ & $0,104(*)$ \\
\hline $\mathrm{X}_{9 \mathrm{~d}}:$ Markets served - International & $0,115\left(^{*}\right)$ & 0,110 (NS) & 0,092 (NS) \\
\hline $\mathrm{X}_{11}:$ Human capital & $0,120\left(^{*}\right)$ & $0,122(*)$ & $0,102\left({ }^{*}\right)$ \\
\hline $\mathrm{X}_{19}:$ Micro-enterprise growth & $0,214\left({ }^{* *}\right)$ & $0,225(* *)$ & $0,189(* *)$ \\
\hline $\mathrm{X}_{21 \mathrm{a}}$ : Success factor - Perseverance and determination & 0,010 (NS) & $0,020(\mathrm{NS})$ & 0,017 (NS) \\
\hline $\mathrm{X}_{21 \mathrm{~b}}:$ Success factor - Business experience & $-0,110(\mathrm{NS})$ & $-0,112\left(^{*}\right)$ & $-0,094\left(^{*}\right)$ \\
\hline
\end{tabular}




\begin{tabular}{|c|c|c|c|}
\hline Investigated variables & Pearson's $\mathrm{r}$ & $\begin{array}{l}\text { Spearman's } \\
\text { rho }(\rho)\end{array}$ & $\begin{array}{l}\text { Kendall's tau } \\
(\tau)\end{array}$ \\
\hline $\begin{array}{l}\mathrm{X}_{21 \mathrm{c}}: \text { Success factor -Woman's entrepreneurial } \\
\text { personality traits }\end{array}$ & $0,128\left(^{*}\right)$ & $0,123\left({ }^{*}\right)$ & $0,104\left(^{*}\right)$ \\
\hline $\mathrm{X}_{21 \mathrm{~d}}$ : Success factor - Previous industry experience & $0,151(* *)$ & $0,155(* *)$ & $0,130(* *)$ \\
\hline $\mathrm{X}_{21 \mathrm{e}}:$ Success factor - Finding a market niche & $0,007(\mathrm{NS})$ & $0,016(\mathrm{NS})$ & $0,013(\mathrm{NS})$ \\
\hline $\mathrm{X}_{21 \mathrm{f}}$ S Success factor - Family members' support & $-0,045(\mathrm{NS})$ & $-0,040(\mathrm{NS})$ & $-0,034$ (NS) \\
\hline $\begin{array}{l}\mathrm{X}_{21 \mathrm{~g}}: \text { Success factor - Exploitation of market } \\
\text { opportunities }\end{array}$ & 0,076 (NS) & 0,067 (NS) & 0,056 (NS) \\
\hline $\mathrm{X}_{21 \mathrm{~h}}:$ Success factor - Other success factor & 0,065 (NS) & $0,064(\mathrm{NS})$ & 0,054 (NS) \\
\hline $\mathrm{X}_{21 \mathrm{i}}:$ No success achieved & $-0,214(* *)$ & $-0,225(* *)$ & $-0,189\left(^{* *}\right)$ \\
\hline $\mathrm{X}_{23}:$ Business plan & $0,126\left(^{*}\right)$ & $0,134\left(^{*}\right)$ & $0,112\left(^{*}\right)$ \\
\hline $\mathrm{X}_{25 \mathrm{a}}:$ Customers served - Retail & $-0,165\left(^{* *}\right)$ & $-0,160(* *)$ & $-0,135\left(^{* *}\right)$ \\
\hline $\mathrm{X}_{25 \mathrm{~b}}$ : Customers served - Micro and small enterprises & $0,021(\mathrm{NS})$ & $0,013(\mathrm{NS})$ & $0,011(\mathrm{NS})$ \\
\hline $\begin{array}{l}\mathrm{X}_{25 c}: \text { Customers served - Medium-size and large } \\
\text { enterprises }\end{array}$ & $0,174\left(^{* *}\right)$ & $0,176(* *)$ & $0,148(* *)$ \\
\hline $\mathrm{X}_{27}:$ Financial capital & $0,139\left(^{*}\right)$ & $0,138\left(^{*}\right)$ & $0,116\left({ }^{*}\right)$ \\
\hline $\mathrm{X}_{30}:$ Business strategy & $0,147(* *)$ & $0,159(* *)$ & $0,134(* *)$ \\
\hline $\begin{array}{l}\mathrm{X}_{32 \mathrm{a}}: \text { Business strategy - Offering distinctive products } \\
\text { / services }\end{array}$ & 0,007 (NS) & $0,022(\mathrm{NS})$ & 0,019 (NS) \\
\hline $\begin{array}{l}\mathrm{X}_{32 \mathrm{~b}}: \text { Business strategy - Improvement of customer } \\
\text { service }\end{array}$ & $0,121\left(^{*}\right)$ & $0,110(\mathrm{NS})$ & 0,092 (NS) \\
\hline $\begin{array}{l}\mathrm{X}_{32 c}: \text { Business strategy - Offering new products / } \\
\text { services }\end{array}$ & $-0,111(\mathrm{NS})$ & $-0,105$ (NS) & $-0,088$ (NS) \\
\hline $\begin{array}{l}\mathrm{X}_{32 \mathrm{~d}}: \text { Business strategy - Marketing and advertising of } \\
\text { products / services }\end{array}$ & $0,044(\mathrm{NS})$ & $0,056(\mathrm{NS})$ & 0,047 (NS) \\
\hline $\begin{array}{l}\mathrm{X}_{32 \mathrm{e}}: \text { Business strategy - Adaptation of products / } \\
\text { services features to client needs }\end{array}$ & 0,059 (NS) & 0,066 (NS) & 0,056 (NS) \\
\hline $\mathrm{X}_{32 \mathrm{f}}:$ Business strategy - Other strategy used & 0,097 (NS) & 0,093 (NS) & 0,078 (NS) \\
\hline $\mathrm{X}_{32 \mathrm{~g}}:$ No business strategy used & $-0,147(* *)$ & $-0,159(* *)$ & $-0,134(* *)$ \\
\hline $\mathrm{X}_{34 \mathrm{a}}:$ Age (up to 39 years) & $0,327(* *)$ & $0,334(* *)$ & $0,281\left({ }^{* *}\right)$ \\
\hline $\mathrm{X}_{34 \mathrm{~b}}:$ Age ( 40 to 49 years) & $-0,026(\mathrm{NS})$ & $-0,037(\mathrm{NS})$ & $-0,031$ (NS) \\
\hline $\mathrm{X}_{34 c}:$ Age (50 to 59 years) & $-0,251(* *)$ & $-0,248(* *)$ & $-0,209\left({ }^{* *}\right)$ \\
\hline $\mathrm{X}_{34 \mathrm{~d}}:$ Age (60 and more years) & $-0,121\left(^{\star}\right)$ & $-0,120\left(^{\star}\right)$ & $-0,101\left(^{\star}\right)$ \\
\hline $\mathrm{X}_{35}:$ Education level (university and higher) & $0,216\left({ }^{* *}\right)$ & $0,220\left(^{* *}\right)$ & $\left.0,185{ }^{(* *}\right)$ \\
\hline $\mathrm{X}_{40}:$ Entrepreneurial orientation & $0,365(* *)$ & $0,368(* *)$ & $0,272(* *)$ \\
\hline $\mathrm{X}_{41}$ : Growth orientation & $0,182(* *)$ & $0,166(* *)$ & $0,122(* *)$ \\
\hline $\begin{array}{l}\mathrm{X}_{42}: \text { Usage of information and communication } \\
\text { technology (ICT) }\end{array}$ & $0,122\left(^{\star}\right)$ & $0,131\left(^{*}\right)$ & $0,094\left(^{*}\right)$ \\
\hline $\mathrm{X}_{43}:$ Social capital & $0,157(* *)$ & $0,158(* *)$ & $0,115\left({ }^{(*}\right)$ \\
\hline
\end{tabular}




\begin{tabular}{|c|c|c|c|}
\hline Investigated variables & Pearson's $r$ & $\begin{array}{c}\text { Spearman's } \\
\text { rho }(\rho)\end{array}$ & $\begin{array}{c}\text { Kendall's tau } \\
(\tau)\end{array}$ \\
\hline \multicolumn{4}{|l|}{ 3. Control variables: } \\
\hline $\mathrm{X}_{5 \mathrm{a}}:$ Business location - Warsaw & $-0,044$ (NS) & $-0,045$ (NS) & $-0,038(\mathrm{NS})$ \\
\hline $\mathrm{X}_{5 \mathrm{~b}}:$ Business location - Other city & 0,020 (NS) & 0,009 (NS) & 0,007 (NS) \\
\hline $\mathrm{X}_{5 \mathrm{c}}:$ Business location - Village & $0,040(\mathrm{NS})$ & $0,058(\mathrm{NS})$ & 0,049 (NS) \\
\hline $\mathrm{X}_{7}$ : Legal form & $0,123\left(^{*}\right)$ & $0,119\left({ }^{*}\right)$ & $0,100(*)$ \\
\hline $\mathrm{X}_{10 \mathrm{a}}:$ Economic activity classification - Services & $0,186\left({ }^{* *}\right)$ & $0,174(* *)$ & $0,146(* *)$ \\
\hline $\mathrm{X}_{10 \mathrm{~b}}:$ Economic activity classification - Trade & $-0,151(* *)$ & $-0,142\left(^{*}\right)$ & $-0,119\left(^{*}\right)$ \\
\hline $\mathrm{X}_{10 c}:$ Economic activity classification - Other & $-0,086$ (NS) & $-0,080$ (NS) & $-0,067$ (NS) \\
\hline $\mathrm{X}_{14 \mathrm{a}}:$ Micro-enterprise size (No employees) & 0,094 (NS) & 0,097 (NS) & 0,082 (NS) \\
\hline $\mathrm{X}_{14 \mathrm{~b}}:$ Micro-enterprise size ( 1 to 5 employees) & $-0,149(* *)$ & $-0,150\left({ }^{* *}\right)$ & $-0,126\left({ }^{* *}\right)$ \\
\hline $\mathrm{X}_{14 \mathrm{c}}:$ Micro-enterprise size (6 to 9 employees) & 0,093 (NS) & 0,100 (NS) & 0,084 (NS) \\
\hline $\mathrm{X}_{14 \mathrm{~d}}:$ Micro-enterprise size ( 10 or more employees) & $0,033(\mathrm{NS})$ & 0,019 (NS) & 0,016 (NS) \\
\hline
\end{tabular}

Note: The sample size is $n=309$ observations. Abbreviations and symbols used for each reported correlation coefficient's value are: (NS) for "Not statistically significant"; $\left.{ }^{*}\right)$ for $\mathrm{p}<0,05$; $\left.{ }^{* *}\right)$ for $\mathrm{p}<0,01$ level and $\left({ }^{* * *}\right)$ for $\mathrm{p}<0,001$ level. All correlation coefficients were calculated using a two-tailed test of statistical significance.

S ource: own elaboration.

In turn, the values of the correlation coefficients for "Business experience", "Age - 50 to 59 years", "No success achieved" and "Markets served - Local" were found to be the predictors that displayed the highest level of negative associations with the measured dependent variable "Composite business performance". However, only the "Business experience" variable was (relatively) moderately strong in terms of the size of the effect.

\section{Presentation of Study Findings: Evaluation of Multivariate Regression Models}

The rationale for using multivariate regression models in this study was to identify the best combination of plausible business success predictors, previously evaluated with the three correlation coefficients (see Table 2), which positively influenced the predicted dependent variable "Composite business performance". The objective of adopting this analytical method was to identify an empirical model with the highest explanatory power as measured by the adjusted coefficient of multiple determination (the adjusted $\mathrm{R}^{2}$ ).

Table 3 presents a summary of key statistics used to evaluate the three multivariate regression models $\mathrm{A}, \mathrm{B}$ and $\mathrm{C}$. These models were constructed based on the variable groupings shown in the theoretical research model presented in Figure 1. Consequently, "Model B" comprises plausible business success predictors grouped within the characteristic 
features of the woman micro-entrepreneur dimension of the theoretical research model. In turn, "Model C" depicts the independent variables categorized within the characteristics and resources of the female-owned firm research dimension of the theoretical research model. "Model A" includes all plausible success predictors shown within the two variable groupings of the theoretical research model.

\section{TABLE 3. Summary statistics for "Model A", "Model B" and "Model C" evaluated with multivariate regression analysis}

\begin{tabular}{|l|c|c|c|}
\hline \multicolumn{1}{|c|}{ Model evaluation statistics } & Model A & Model B & Model C \\
\hline Coefficient of multiple correlation R & 0,650 & 0,600 & 0,533 \\
\hline Coefficient of multiple determination R squared (in \%) & $42,3 \%$ & $36,0 \%$ & $28,4 \%$ \\
\hline Adjusted coefficient of multiple determination R squared (in \%) & $36,1 \%$ & $31,5 \%$ & $22,3 \%$ \\
\hline ANOVA F-test value & 6,796 & 8,083 & 4,687 \\
\hline ANOVA F-test significance level & 0,000 & 0,000 & 0,000 \\
\hline Number of observations (n) & 309 & 309 & 309 \\
\hline
\end{tabular}

Note: The dependent variable investigated "Composite business performance" was extracted with exploratory factor analysis and calculated as a combined scale (a mean of four performance-related items).

Source: own elaboration.

Our ANOVA (the analysis of variance) results indicate that there is sufficient evidence to reject the null hypothesis which posits that the investigated combination of predictors included in the three investigated regression models do not fit the sample data better than the baseline model containing only the intercept. This is because the ANOVA F-test values are statistically significant for all investigated models at the $p<0,001$ level. As a result, all three evaluated models include regression coefficients that are found to be statistically significantly different from zero. "Model A" $\left(\mathrm{R}^{2}=42,3 \%\right)$ displayed the highest explanatory power (the largest expected effect size) of the predicted dependent variable while "Model $C^{\prime \prime}\left(R^{2}=28,4 \%\right)$ showed the lowest explanatory power (the smallest expected effect size). The

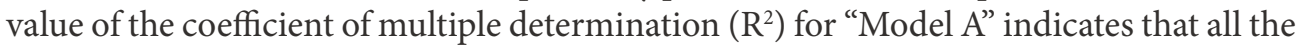
business success predictors and control variables - included in this model - explained as much as $42,3 \%$ of the variation in the predicted dependent variable "Composite business performance". In terms of its overall goodness of fit, "Model A" may be regarded as the one with a medium size of the expected effect considering the achieved $\mathrm{R}^{2}$ for 309 observations.

However, the adjusted coefficient of multiple determination (the adjusted $\mathrm{R}^{2}$ ) is a much better indicator of the regression model evaluation because it shows how much variation in the "Composite business performance" can be expected if it has been derived from the population from which the sample was drawn. Thus, this statistic shows the loss of the predictive power of the investigated model [Field, 2013]. In the case of "Model A", which displays the highest explanatory power, the net effect of this adjustment reduced the $\mathrm{R}^{2}$ 
value from $42,3 \%$ to $36,1 \%$ or by $6,2 \%$. As a result, we can conclude that the adjusted $\mathrm{R}^{2}$ shows some decrease in the explanatory power of "Model A" due to the inclusion of 25 potential success predictors and five control variables in the multivariate regression analysis. However, in the case of "Model C", which showed the lowest explanatory power, the net effect of the adjustment decreased the value of $\mathrm{R}^{2}$ from $28,4 \%$ to $22,3 \%$ or by $6,1 \%$. The loss of predictive power of "Model C" is similar in percentage terms to that of "Model A".

\section{TABLE 4. The estimates of unstandardized (Bs) and standardized (Betas) regression coefficients and their $t$-test statistical significance value for "Model $A$ "}

\begin{tabular}{|c|c|c|c|c|c|}
\hline \multirow{2}{*}{$\begin{array}{l}\text { Description of predictors and control } \\
\text { variables for "Model A" }\end{array}$} & \multicolumn{2}{|c|}{$\begin{array}{c}\text { Unstandardized } \\
\text { Regression } \\
\text { Coefficients }\end{array}$} & \multirow{2}{*}{$\begin{array}{c}\begin{array}{c}\text { Standardized } \\
\text { Regression } \\
\text { Coefficients }\end{array} \\
\text { Beta }(\beta)\end{array}$} & \multirow[t]{2}{*}{$t$-test } & \multirow{2}{*}{$\begin{array}{l}\text { Significancep- } \\
\quad \text {-value }\end{array}$} \\
\hline & B & $\begin{array}{l}\text { Standard } \\
\text { Error }\end{array}$ & & & \\
\hline Intercept (constant) & 1,146 & 0,638 & & 1,796 & $0,074(\#)$ \\
\hline $\mathrm{X}_{34 \mathrm{a}}:$ Age (up to 39 years) & 0,751 & 0,208 & 0,226 & 3,608 & $0,000(* * *)$ \\
\hline $\mathrm{X}_{34 \mathrm{~b}}:$ Age (40 to 49 years) & 0,336 & 0,211 & 0,091 & 1,593 & 0,112 (NS) \\
\hline $\mathrm{X}_{40}$ : Entrepreneurial orientation & 0,311 & 0,086 & 0,198 & 3,606 & $0,000(* * *)$ \\
\hline $\begin{array}{l}\mathrm{X}_{21 \mathrm{~d}} \text { : Success factor - Previous industry } \\
\text { experience }\end{array}$ & 1,082 & 0,294 & 0,180 & 3,683 & $0,000(* * *)$ \\
\hline $\begin{array}{l}\mathrm{X}_{32 \mathrm{~b}}: \text { Business strategy - Improvement of } \\
\text { customer service }\end{array}$ & 0,569 & 0,256 & 0,120 & 2,224 & $0,027\left(^{*}\right)$ \\
\hline $\begin{array}{l}\mathrm{X}_{32 \mathrm{~d}}: \text { Business strategy - Marketing and } \\
\text { advertising of products / services }\end{array}$ & 0,284 & 0,373 & 0,040 & 0,760 & 0,448 (NS) \\
\hline $\mathrm{X}_{32 \mathrm{f}}:$ Business strategy - Other strategy used & 0,414 & 0,236 & 0,095 & 1,758 & $0,080(\#)$ \\
\hline $\mathrm{X}_{9 \mathrm{c}}:$ Markets served - Domestic & 0,414 & 0,198 & 0,111 & 2,091 & $0,037(*)$ \\
\hline $\mathrm{X}_{9 \mathrm{~d}}:$ Markets served - International & 0,541 & 0,230 & 0,124 & 2,353 & $0,019\left(^{*}\right)$ \\
\hline $\mathrm{X}_{5 \mathrm{~b}}:$ Business location - Other city & 0,349 & 0,175 & 0,099 & 1,989 & $0,048(*)$ \\
\hline $\mathrm{X}_{7}:$ Legal form & 0,078 & 0,387 & 0,013 & 0,202 & 0,840 (NS) \\
\hline $\mathrm{X}_{4}$ : Business partners & 0,301 & 0,234 & 0,084 & 1,291 & 0,198 (NS) \\
\hline $\begin{array}{l}\mathrm{X}_{25}: \text { Customers served - Medium-size and } \\
\text { large enterprises }\end{array}$ & 0,363 & 0,196 & 0,095 & 1,854 & $0,065(\#)$ \\
\hline $\mathrm{X}_{27}:$ Financial capital & 0,480 & 0,197 & 0,121 & 2,434 & $0,016(*)$ \\
\hline $\mathrm{X}_{35}:$ Education level (university and higher) & 0,444 & 0,193 & 0,114 & 2,301 & $0,022(*)$ \\
\hline $\mathrm{X}_{41}:$ Growth orientation & 0,066 & 0,076 & 0,048 & 0,864 & 0,388 (NS) \\
\hline $\begin{array}{l}\mathrm{X}_{10 \mathrm{a}}: \text { Economic activity classification } \\
- \text { Services }\end{array}$ & 0,317 & 0,185 & 0,088 & 1,717 & $0,087(\#)$ \\
\hline $\mathrm{X}_{11}:$ Human capital & 0,973 & 0,416 & 0,302 & 2,341 & $0,020\left(^{*}\right)$ \\
\hline
\end{tabular}




\begin{tabular}{|c|c|c|c|c|c|}
\hline \multirow{2}{*}{$\begin{array}{l}\text { Description of predictors and control } \\
\text { variables for "Model A" }\end{array}$} & \multicolumn{2}{|c|}{$\begin{array}{l}\text { Unstandardized } \\
\text { Regression } \\
\text { Coefficients }\end{array}$} & \multirow{2}{*}{$\begin{array}{c}\begin{array}{c}\text { Standardized } \\
\text { Regression } \\
\text { Coefficients }\end{array} \\
\text { Beta }(\beta)\end{array}$} & \multirow[t]{2}{*}{$t$-test } & \multirow{2}{*}{$\begin{array}{l}\text { Significancep- } \\
\text {-value }\end{array}$} \\
\hline & B & $\begin{array}{l}\text { Standard } \\
\text { Error }\end{array}$ & & & \\
\hline $\begin{array}{l}X_{150}: \text { Micro-enterprise size - Revenue } \\
(500000 \text { to } 1000000 \text { PLN) }\end{array}$ & 0,591 & 0,277 & 0,105 & 2,130 & $0,034(*)$ \\
\hline $\mathrm{X}_{16 \mathrm{a}}:$ Business goal - Personal & 0,066 & 0,156 & 0,021 & 0,423 & $0,672(\mathrm{NS})$ \\
\hline $\mathrm{X}_{30}$ : Business strategy & 0,141 & 0,206 & 0,042 & 0,684 & 0,495 (NS) \\
\hline $\begin{array}{l}\mathrm{X}_{38 \mathrm{~d}}: \text { Managerial competency - Planning } \\
\text { and analysis skills }\end{array}$ & 0,211 & 0,268 & 0,038 & 0,790 & 0,430 (NS) \\
\hline $\begin{array}{l}\mathrm{X}_{21 \mathrm{c}} \text { : Success factor -Woman's } \\
\text { entrepreneurial personality traits }\end{array}$ & 0,273 & 0,232 & 0,058 & 1,180 & 0,239 (NS) \\
\hline $\mathrm{X}_{2 \mathrm{lh}}:$ Success factor - Other success factor & 0,233 & 0,317 & 0,036 & 0,737 & $0,462(\mathrm{NS})$ \\
\hline $\mathrm{X}_{23}$ : Business plan & $-0,255$ & 0,166 & $-0,077$ & $-1,541$ & 0,124 (NS) \\
\hline $\mathrm{X}_{43}$ : Social capital & $-0,114$ & 0,074 & $-0,082$ & $-1,537$ & 0,125 (NS) \\
\hline $\begin{array}{l}\mathrm{X}_{42}: \text { Usage of information and } \\
\text { communication technology (ICT) }\end{array}$ & $-0,023$ & 0,062 & $-0,021$ & $-0,375$ & 0,708 (NS) \\
\hline $\mathrm{X}_{8}$ : Business experience & $-0,041$ & 0,013 & $-0,178$ & $-3,067$ & $0,002(* *)$ \\
\hline $\begin{array}{l}\mathrm{X}_{37}: \text { Managerial competencies usefulness for } \\
\text { success in business }\end{array}$ & $-0,187$ & 0,241 & $-0,037$ & $-0,775$ & 0,439 (NS) \\
\hline $\mathrm{X}_{14 \mathrm{a}}:$ Micro-enterprise size (No employees) & $-0,698$ & 0,418 & $-0,216$ & $-1,670$ & $0,096(\#)$ \\
\hline
\end{tabular}

Note: The dependent variable is "Y: Composite business performance" (combined scale calculated as a mean of four performance-related items). Number of observations is $n=309$. Abbreviations for each reported statistical significance value of the $t$-test are: (NS) for "Not statistically significant"; (\#) for $\mathrm{p}<0,10$; $\left(^{*}\right)$ for $\mathrm{p}<0,05$; $\left(^{* *}\right)$ for $\mathrm{p}<0,01$ and $\left(^{* * *}\right.$ ) for $\mathrm{p}<0,001$ level. Source: own elaboration.

Table 4 shows the estimates of the unstandardized (Bs) and standardized (Betas) regression coefficients for "Model A", which was found to be the best in terms of its explanatory power $\left(\mathrm{R}^{2}=42,3 \%\right.$; adjusted $\left.\mathrm{R}^{2}=36,1 \%\right)$. All business success predictors and control variables were included in the model using the "enter" method. The standardized regression coefficients (Betas or $\beta$ ) indicate the importance of the contribution of each evaluated business success predictor. Thus, the larger its absolute value the greater its impact (positive or negative) on the predicted dependent variable [Field, 2013].

Specifically, in order of magnitude of positive effect, the independent variables "Human capital", "Age (up to 39 years)", "Entrepreneurial orientation", "Success factor - Previous industry experience", "Markets served - International", "Financial capital", "Business strategy - Improvement of customer service", "Education level (university and higher)", "Markets served - Domestic", "Customers served - Medium-size and large enterprises", and "Business strategy - Other strategy used" were the most favorable performance predictors of women-owned micro-enterprises from the region during 2011-2013. Surprisingly, 
the independent variable "Business experience", measured in number of years, adversely affected the business performance of the firms under study.

In the case of control variables, "Micro-enterprise size - Revenue (500 000 to 1000000 PLN)", "Business location - Other city" and "Economic activity classification - Services" displayed a positive, but small impact on the performance of women-owned firms. "Micro-enterprise size (No employees)" had an adverse influence on the studied dependent variable, while "Legal form" was not statistically significant in terms of its influence on the success of the female-owned micro-enterprises.

The analysis of diagnostics for "Model A" showed that it did not suffer from a multicollinearity problem because the VIF statistic's (variance inflation factors) values were below 10 for all investigated independent and control variables [Field, 2013]. In turn, the "casewise diagnostics" of the standardized residuals showed that no more than $5 \%$ of observations in the data had absolute values above two standard deviations. Moreover, no outliers were detected [Field, 2013]. The Durbin-Watson test for serial correlations between errors in "Model A" amounted to 1,861. This figure indicates that the residuals in this model are uncorrelated [Field, 2013]. In summary, the diagnostics statistics for "Model A" showed that it is sufficiently able to predict the values of the examined dependent variable "Composite business performance".

\section{Discussion of Study Results}

This study examined plausible business success predictors contributing to the success of women-owned and co-owned micro-enterprises from the Mazovia Voivodeship in Poland. Business success was measured by the dependent variable "Composite business performance". The success predictors were grouped within two research categories, namely: the characteristics of a woman micro-entrepreneur, and the characteristics of (and the resources owned by) the micro-enterprise (see Figure 1).

Regarding the first grouping category, factors that favorably influence the performance of women-owned and co-owned micro-enterprises in the region are: "Age (up to 39 years)", "Entrepreneurial orientation", "Success factor - Previous industry experience", "Business strategy - Improvement of customer service", "Business strategy - Other strategy used" and "Education level (university and higher)".

Successful women business owners in the Mazovia Voivodship in Poland are ideally 30-39 years old, with a university degree or finished postgraduate studies. These female micro-entrepreneurs also had several years of full-time prior industry experience before starting their firms. Similar research findings are reported in developed countries across the globe [Taylor, Newcomer, 2005]. However, female participation rates in entrepreneurship vary substantially around the world. For example, in Pakistan only $1 \%$ of women are 
business owners, while as much as $40 \%$ of females in Zambia are engaged in entrepreneurship [Kelley et al., 2013, p. 15].

Women micro-entrepreneurs whose firms achieved superior performance during 2011-2013 had a business strategy to gain an advantage over their competitors in the industry. The most effective strategy was associated with quality improvement, efficiency and timeliness of the customer service provided. This was because most women-owned micro-enterprises studied operated in the consumer services sector. Thus, this study confirms the findings of other investigations that emphasized the importance of identifying and adopting effective strategies, and marketing practices by women small business owners to achieve a competitive advantage over their rivals in the industry [Zapalska et al., 2015].

Successful women micro-entrepreneurs within this region are innovative and assume more risk, but at a moderate level. They also display a greater pro-activeness in adapting to changing customer demand, client preferences, market trends, and competitors' actions. These elements evidence an above average "Entrepreneurial orientation" in the marketplace, and support the literature results that have identified a positive relationship between the entrepreneurial behavior of women business owners and the economic performance of their firms [Iakovleva, Kickul, 2006].

Regarding the second grouping category, the factors that favorably influence the performance of women-owned and co-owned micro-enterprises in the region are: "Human capital", "Markets served - International", "Markets served - Domestic", "Financial capital", as well as "Customers served - Medium-size and large enterprise".

Our research indicates that women micro-entrepreneurs who hire skilled and experienced employees on a full-time or part-time basis (invest in the firm's "Human capital") achieve more favorable business results than those female business owners who are self-employed. Consequently, women-owned firms that operate as self-employed entities may experience more difficulty in successfully competing with larger micro-enterprises in a highly competitive marketplace. By comparison, other scholars who analyzed women's entrepreneurship, focused on the importance of the "Human capital" components associated specifically with female business owners (e.g. completed education, previous industry experience, etc.) and their impact on the success of their firms [Coleman, 2007]. However, the findings of this study emphasize the need for women micro-entrepreneurs to hire, develop and retain skilled workers (the employee "Human capital" component) to ensure the success of their businesses in the future.

The most successful women-owned businesses in Mazovia Voivodeship offered their products and services to customers from many administrative regions of the country ("Markets served - Domestic), and even to clients residing abroad ("Markets served - International"). In a more competitive and globalized business environment, it may no longer be sufficient to cater only to local customers (from borough, county, or provincial markets) in many industries in order to survive. Moreover, women micro-entrepreneurs who are able 
to attract and retain more business sector clients (e.g. "Customers served - Medium-size and large enterprises") also display better performance than those micro-enterprises that focus their attention only on retail clients, served within local markets. Other studies reveal that, in comparison with large enterprises, both female- and male-owned small firms still remain relatively understudied within the context of their market orientation [Elg, 2003]. In developed countries the link between market orientation of firms and their overall business performance has been relatively well-established [Perry, 2014]. However, in transition countries, researchers were not able to find conclusive evidence concerning the relationship between the market segment of customers served (retail versus business clients) and performance of female- and male-owned micro-enterprises [Lemańska-Majdzik, 2009]. These inconclusive results may be associated with a relative scarcity of studies on this topic within the CEE region economies.

The findings of this study indicate that successful female business owners relied primarily on their own resources ("Financial capital") to fund their operational activities and the short to medium-term growth needs of their firms. However, the dependence of these micro-enterprises on the "organic growth strategy" ${ }^{13}$ may restrict their future development unless these firms generate sufficient profit to achieve the owners' long-term business objectives. By contrast, many researchers emphasize the need to seek external sources of financial capital (e.g. business partners, bank loans, etc.) to support the profit and business expansion of their firms [Nordin et al., 2011].

Considering the control variables used in the study, women-owned firms with sales revenue ranging from 500000 to 1000000 PLN, which had a business seat in another city than Warsaw, and operated in the services sector of the economy were found to be the most successful in business during 2011-2013. In turn, female-run firms organized as self-employed entities were the least successful. However, the favorable or adverse impact of these control variables on the examined dependent variable was relatively small, but statistically significant (see Table 4). Some international studies show that specific "firm location" may be a less important factor affecting the success of women-owned businesses in comparison with other contributing variables like "prior industry or work experience", "professional business networks", or “availability of capital” [McGrath Cohoon et al., 2010].

\section{Limitations of the Study}

The main limitation of this study is that the general level of its findings (the external validity) is restricted to the sub-population of women-owned and co-owned micro-enterprises registered within the Mazovia Voivodeship in Poland. This is because research results obtained from only one administrative region may not reflect the views and business practices of female micro-entrepreneurs from other regions of the same country. 
The study was designed as cross-sectional in nature, in which data were collected at a single point in time. This is also a limitation of this research. The statistically significant positive relationships between the investigated variables, observed in the three multivariate regression models $\mathrm{A}, \mathrm{B}$ and $\mathrm{C}$, may not necessarily represent bona fide causal relationships in the long-run. Consequently, a longitudinal design is a logical direction for a follow-up research. Such a study design could show changes in independent variables over time and their impact on the performance of micro-enterprises.

Finally, the identified positive relationship in "Model A" between "Composite business performance" and several investigated independent variables (e.g. "Entrepreneurial orientation", "Business strategy", etc.) may be mediated by several possible moderating variables (e.g. firm size, type of industry, ownership status, enterprise life cycle, state of the economy, etc.). This needs to be empirically verified by future studies structured in a longitudinal design fashion.

\section{Conclusions and Recommendations for Future Research}

The research findings of this study show that the survival and future progress of femaleowned business undertakings in the Poland's transitioning economy may be linked to the presence of key success factors (i.e. business success predictors). These predictors were evaluated using three multivariate regression models A, B and C. "Model A" indicated the highest explanatory power of the predicted dependent variable "Composite business performance" $\left(\mathrm{R}^{2}=42,3\right)$.

Our research findings reveal that the most successful women micro-entrepreneurs within the Mazovia Voivodeship in Poland were typically 30-39 years old; completed a tertiary education level; acquired at least three years of practical business experience; displayed above average entrepreneurial orientation; and had a business strategy to effectively compete with their rivals. Moreover, the superior performing women-owned and co-owned micro-enterprises hired skilled and experienced employees ("Human capital"); offered products or services to domestic and international clients; were able to attract business sector customers; and had sufficient funds to manage their firms ("Financial capital"). Our identification and analysis of these key success factors provides a broader understanding of the entrepreneurial performance of women-owned firms within the context of the Polish experience.

It is recommended that this research be replicated in other administrative regions of Poland (e.g. in less developed provinces like the Warmińsko-Mazurskie Voivodeship) and also within other Central and Eastern Europe countries (e.g. Czech Republic) for comparative purposes. 
Women's entrepreneurship is regarded internationally as "a dynamic social and economic phenomenon" [Leszczyński, 2013, pp. 120-123]. As a result, prospective inquiries may be more insightful if they include independent variables from the process (e.g. the recruitment, training and retention of employees) and business environment (e.g. the nature of maintained relationships with customers and suppliers). These variable groupings may be used to develop complex theoretical models and formulate research hypotheses, which can be verified empirically using structural equation modeling (SEM).

Scholars may also compare the sub-populations of male and female micro-entrepreneurs to obtain a more complete picture of this complex and multidimensional research phenomenon. Such research could detect possible differences in the key success factors that affect the performance of these firms by using gender as the company type grouping variable.

\section{Acknowledgement}

This study was supported by the Polish Ministry of Science and Higher Education grant KGS/BMN/04/14.

\section{Notes}

1 Author’s e-mail address: dariusz.leszczynski@gmail.com.

2 The acronym "PKD-2007" refers to the Polish Classification of Activities (PKD). It is a hierarchically systematized division and coding system of the different types of social-economic activities, in which firms are engaged in [GUS (Central Statistical Office of Poland), 2016].

3 A cross-sectional design refers to the collection of data from many respondents at a single point in time [Bryman, Bell, 2011, p. 53].

4 Women-owned micro-enterprises, eligible for the study, were drawn from a large online database. However, all business contact details (i.e. telephone numbers, e-mails, etc.) were obtained from publicly available websites used by these micro-enterprises and through direct contact with firms' owners. Systematic sampling is a probability sampling method, in which the eligible cases for the study are selected from a sampling frame at established fixed intervals [Bryman, Bell, 2011, p. 719].

5 The target sample size of 3,000 women-owned (e.g. sole proprietorship) or co-owned (e.g. civil law partnership) micro-enterprises was determined by the use of a statistical sample size online calculator, owned by Raosoft. Inc. and an assumed realistic response rate of $10 \%(300 / 0,10)$. The sample size calculator applied in the formula the following variables: the margin of error, the confidence level, the population size and the response distribution [Raosoft, 2004]. 
6 The snowball sampling method is a form of convenience sample, in which the researcher approaches the first eligible respondents for the study, and then uses these contacts to obtain referrals to other potential respondents that are relevant to the research topic under study [Bryman, Bell, 2011, pp. 192-193].

7 Internet survey data collection was outsourced to a professional market research company. This company is a member of the Polish Association of Public Opinion and Marketing Research Firms (OFBOR). More information on this organization and its activities can be obtained by visiting their official Internet website at http://www.ofbor.pl/ [Organizacja Firm Badania Opinii i Rynku (OFBOR), 2016].

8 The achieved response rate was calculated according to the formula recommended by Bryman and Bell [2011, p. 189]. As a result, the response rate $=$ [number of usable questionnaires / (total sample - unsuitable or uncontactable members of the sample) $\mathrm{x} 100 \%$ ]. Thus, the achieved response rate in the study was calculated as $[309 /(3,000-799) \times 100 \%]=14,04 \%$ or about $14 \%$. The hired research company provided the information on the "unsuitable or uncontactable members of the sample".

9 A full description of all variables used in the data analysis process, their level of measurement and the operationalization adopted in the study, was not included in this paper because of article size limitations. Readers interested in this content should contact the author directly by using the e-mail address provided herein.

10 The descriptive statistics of women micro-entrepreneurs from the Mazovia Voivodeship of Poland were calculated based on the sample of $n=309$ observations.

11 In Table 1 the full names of items used in the questionnaire (the investigated variables) that measured each construct (the extracted factor) were replaced with abbreviated labels (e.g. "Item 1", "Item 2", etc.) to condense the data displayed. Readers interested in a full description of the items used in the questionnaire for each measured construct should contact the author directly by using the e-mail address provided herein.

12 According to Field [2013, p. 270], the measure of a correlation coefficient's effect size, which falls within the range from $+/-0,300$ to $+/-0,500$, indicates a medium positive or negative effect in terms of the magnitude of the result.

13 The term "organic growth" means that the firm expands its operations using its own (internal) energy and resources (capabilities) such as retained earnings. It occurs without mergers or acquisitions, but may include some minor takeovers such as the purchase of production facilities [Schwenker, Spremann, 2009, p. 321].

\section{References}

Aldrich, H.E., Carter, N., Ruef, M. (2002), With very little help from their friends: Gender and relational composition of nascent entrepreneurs' startup teams, in: W.D. Bygrave, J.A. Hornaday, D.F. Muzyka, K.H. Vesper and W.E.J. Wetzel (eds.), Frontiers of Entrepreneurship Research, Wellesley, MA: Babson College, [Online], available at: http://fusionmx.babson.edu/entrep/fer/Babson2002/VI/VI_P1/VI_P!. htm, accessed: August 14, 2016.

Bryman, A., Bell, E. (2011), Business Research Methods, Third ed., Oxford: Oxford University Press.

Buttner, D.P., Moore, E.H. (1997), Women Entrepreneurs: Moving Beyond the Glass Ceiling, Thousand Oaks, CA: Sage Publications Inc.

Capelleras, J.L., Greene, F.J. (2008), The determinants and growth implications of venture creation speed, Entrepreneurship and Regional Development, 20(4), pp. 317-343.

Carter, H., Allen, K. (1997), Size determinants of Women-owned Businesses: Choice or Barriers to Resources?, Entrepreneurship and Regional Development, 9(3), pp. 211-220. 
Carter, S., Anderson, S., Shaw, E. (2001), Women's Business Ownership: A Review of the Academic, Popular and Internet Literature, Report to the Small Business Service, Glasgow: The University of Strathclyde, Department of Marketing, [Online], available at: http://webarchive.nationalarchives.gov.uk/20090609003228/http://www.berr. gov.uk/files/file38362.pdf, accessed: March 3, 2016.

Carter, S., Marlow, S., Bennett, D. (2012), Gender and entrepreneurship, in: S. Carter and D. Jones-Evans (eds.), Enterprise and small business: Principles, Practice and Policy, Harlow: Pearson Education Limited, pp. 218-231. Coleman, S. (2007), The Role of Human and Financial Capital in the Profitability and Growth of Women-Owned Small Firms", Journal of Small Business Management, 45(3), pp. 303-319.

Davidsson, P., Honig, B. (2003), The role of social and human capital among nascent entrepreneurs, Journal of Business Venturing, 18(3), pp. 301-331.

Davidsson, P., Achtenhagen, L., Naldi, L. (2010), Small Firm Growth, Foundations and Trends ${ }^{\varpi}$ in Entrepreneurship, 6(2), pp. 69-166.

De Bruin, A., Brush, C.G., Welter, F. (2006), Introduction to the Special Issue: Towards Building Cumulative Knowledge on Women's Entrepreneurship, Entrepreneurship Theory and Practice, 30(5), pp. 585-593.

Elg, U. (2003), Retail market orientation: A preliminary framework, International Journal of Retail \& Distribution Management, 31(2), pp. 107-117.

Field, A. (2013), Discovering Statistics using IBM SPSS Statistics, Fourth ed., London: SAGE Publications Ltd.

Fielden, S.L., Davidson, M.J. (2010), Introduction, in: S.L. Fielden and M.J. Davidson (eds.), International Research Handbook on Successful Women Entrepreneurs, Cheltenham: Edward Elgar Publishing Limited, pp. 1-9.

Fischer, E., Reuber, A.R., Dyke, L. (1993), A theoretical overview and extension of research on sex, gender, and entrepreneurship, Journal of Business Venturing, 8(2), pp. 151-168.

Gartner, W. (1985), A conceptual framework for describing the phenomenon of new venture creation, Academy of Management Review, 10(4), pp. 696-706.

Grant, R.M. (2010), Contemporary Strategy Analysis: Text and Cases. Seventh ed., Chichester: John Wiley \& Sons Ltd. GUS (Central Statistical Office of Poland), (2016), Information portal: Classifications, [Online], available at: http://stat.gov.pl/en/metainformations/classifications, accessed: February 11, 2016.

Guzowska, M. (2011), Mazovia in brief: Economy, [Online], available at: http://www.mazovia.pl/en/shortly-about-mazovia/mazovia-in-brief/art,2, economy.html, accessed: February 11, 2016.

Hair Jr., J.F., Black, W.C., Babin, B.J., Anderson, R.E. (2014), Multivariate Data Analysis, Seventh ed., Harlow: Pearson Education Limited.

Iakovleva, T., Kickul, J. (2006), Personal and Organizational Success Factors of Women Small and Medium Enterprises (SMEs) in Russia, Center for Gender in Organizations, Working paper, October, No. 21, Boston, MA: Simmons School of Management.

Investopedia, (2016), Human Capital, [Online], available at: http://www.investopedia.com/terms/h/humancapital. asp, accessed: February 11, 2016.

Jennings, J.E., Brush, C.G. (2013), Research on Women Entrepreneurs: Challenges to (and from) the Broader Entrepreneurship Literature, The Academy of Management Annals, 7(1), pp. 661-713.

Kelley, D.J., Brush, C.G., Greene, P.G., Litovsky, Y. (2011), Global Entrepreneurship Monitor: 2010 Women's Report, Wellesley, MA: Babson College and Global Entrepreneurship Research Association (GERA).

Kelley, D.J., Brush, C.G., Greene, P.G., Litovsky, Y. (2013), Global Entrepreneurship Monitor: 2012 Women's Report, Wellesley, MA: Babson College and Global Entrepreneurship Research Association (GERA).

Kelley, D.J., Brush, C.G., Greene, P.G., Herrington, M., Ali, A., Kew, P. (2015), Global Entrepreneurship Monitor: Women's Entrepreneurship 2015, Wellesley, MA: Babson College and Global Entrepreneurship Research Association (GERA). 
Lemańska-Majdzik, A., (2009), Czynniki sukcesu firm powstałych w wyniku samozatrudnienia, Częstochowa: Sekcja Wydawnictwa Wydziału Zarządzania Politechniki Częstochowskiej.

Leszczyński, D. (2013), The investigation into motivations, success factors and barriers among women small business owners: An overview of extant literature, International Journal of Management and Economics, No. 39, July-September, pp. 108-125.

Lumpkin, G.T., Dess, G.G. (2001), Linking two dimensions of entrepreneurial orientation to firm performance: The moderating role of environment and industry life cycle, Journal of Business Venturing, 16(5), pp. 429-451. McAdam, M. (2013), Female Entrepreneurship, First ed., Abingdon: Routledge.

McGrath Cohoon, J., Wadhwa, V., Mitchell, L. (2010), The anatomy of an entrepreneur: Are successful women entrepreneurs different from men?, Kansas City, MO: Ewing Marion Kauffman Foundation.

Merriam-Webster, (2015), Merriam-Webster Dictionary: Success, [Online], available at: http://www.merriam-webster.com/dictionary/success, accessed: February 10, 2016.

Minniti, M., Arenius, P., Langowitz, N., (2005), Global Entrepreneurship Monitor: 2004 Report on Women and Entrepreneurship, Wellesley, MA: The Center for Women's Leadership at Babson College.

Nordin, N.A.M., Abdul-Hamid, A., Woon, C.C. (2011), Factors affecting profitability of women entrepreneurs' business in Malaysia, Annual Summit on Business and Entrepreneurial Studies (ASBES 2011), Kuching, Sarawak, Malaysia, pp. 972-985.

Organizacja Firm Badania Opinii i Rynku (OFBOR), (2016), Strona Główna - Organizacja, [Online], available at: http://www.ofbor.pl/index.php?option=com_content\&view=article\&id=12\&Itemid=5, accessed: February 11, 2016.

Orhan, M. (2005), Why women enter into small business ownership, in: S.L. Fielden and M.J. Davidson (eds.), International Handbook of Women and Small Business Entrepreneurship, Cheltenham: Edward Elgar Publishing Limited, pp. 3-16.

Oxford University Press, (2016), Oxford Dictionaries: Growth, [Online], available at: http://www.oxforddictionaries.com/definition/english/growth, accessed: February 10, 2016.

Parker, S.C. (2009), The Economics of Entrepreneurship, First ed., Cambridge: Cambridge University Press.

PARP, (2011), Women Entrepreneurship in Poland, Warsaw: Polish Agency for Enterprise Development (PARP).

Perry, M. (2014), Market orientation in small businesses: creative or lacking, The Marketing Management Journal, 24(1), pp. 96-107.

Raosoft (2004), Sample size calculator, [Online], available at: http://www.raosoft.com/samplesize.html, accessed: August 20, 2016.

Ramadani, V., Gërguri-Rashiti, S., Fayolle, A. (2015), Introduction: Female Entrepreneurship in Transition Economies as a Significant but Understudied Field, in: V. Ramadani, S. Gërguri-Rashiti and A. Fayolle (eds.), Female Entrepreneurship in Transition Economies: Trends and Challenges, Basingstoke: Macmillan Publishers Limited, pp. 1-8.

Rauch, A., Wiklund, G.T., Frese, M. (2009), Entrepreneurial orientation and business practice: an assessment of past research and suggestions for the future, Entrepreneurship Theory and Practice, 33(3), pp. 761-787.

Robichaud, Y., Cachon, J., Haq, R. (2010), Motives, Success Factors, and Barriers among Canadian Female Entrepreneurs: The Case of Greater Sudbury, Entrepreneurial Practice Review, 1(2), pp. 36-65.

Schwenker, B., Spremann, K. (2009), Management between Strategy and Finance: The Four Seasons of Business, First ed., Heidelberg: Springer-Verlag.

Stair Jr, R.M., Crittenden, W.F., Crittenden, V.L. (1989), The use, operation, and control of the small business computer, Information \& Management, 16(1), pp. 125-130. 
Taylor, S.R., Newcomer, J.D. (2005), Characteristics of women small business owners. in: S.L. Fielden and M.J. Davidson (eds.), International Handbook of Women and Small Business Entrepreneurship, Cheltenham: Edward Elgar Publishing Limited, pp. 17-31.

Valencia, M. (2007), Past female entrepreneurship with the stress on the future in the new economy globalization, in: M. Radović Marković (ed.), The Perspective of Women's Entrepreneurship in the Age of Globalisation, Charlotte, NC: Information Age Publishing Inc., pp. 13-23.

Watson, J., Robinson, S. (2003), Adjusting for risk in comparing the performance of male- and female-controlled SMEs, Journal of Business Venturing, 18(6), pp. 773-788.

Westhead, P., Howorth, C. (2006), Ownership and Management Issues Associated with Family Firm Performance and Company Objectives, Family Business Review, 19(4), pp. 301-316.

Yordanova, D.I. (2011), The effects of gender on entrepreneurship in Bulgaria: An empirical study, International Journal of Management, 28(1), pp. 289-305.

Zapalska, A., Bugaj, M., Rudd, D. (2005), Female Entrepreneurship in Transition Polish Economy, Problems and Perspectives in Management Journal, Issue 2, pp. 32-39.

Zapalska, A.M., Brozik, D., Zieser, N. (2015), Factors affecting success of small business enterprises in the Polish tourism industry, Tourism, 63(3), pp. 365-381.

Zikmund, W.G., Babin, B.J., Carr, J.C., Griffin, M. (2009), Business Research Methods, Eighth ed., Mason, OH: South-Western College Publications \& Cengage Learning. 